\title{
Growth and performance curve of dairy goats fed with detoxified castor bean cake by different alkaline solutions
}

\section{Curva de crescimento e desempenho de cabras leiteiras alimentadas com torta de mamona destoxificada por diferentes soluções alcalinas}

\author{
Ricardo Alves de Araújo ${ }^{1 *}$; Roberto Cláudio Fernandes Franco Pompeu²; Marcos \\ Cláudio Pinheiro Rogério ${ }^{2}$; Hévila Oliveira Salles²; Clésio dos Santos Costa ${ }^{3}$; \\ Renato Gomes Fontinele ${ }^{4}$; Luiza de Nazaré Carneiro da Silva ${ }^{5}$; José Neuman \\ Miranda Neiva ${ }^{6}$
}

\section{Highlights:}

Detoxified castor cake by $\mathrm{Ca}(\mathrm{OH})_{2}$ and $\mathrm{NaOH}$ have potential to replace soybean meal.

Both castor cakes decrease intake and improve feed conversion.

Logistic mathematical model accurately estimates the growth goats' kids.

The absolute growth rate is greater in Anglo Nubian goats.

\begin{abstract}
This study aimed to evaluate the influence of the substitution of soybean meal (SM) by detoxified castor cake (DCC) by two alkaline products on intake, performance and on the growth curve of goat's kids. 24 were used, Saanen goats $(\mathrm{n}=12)$ and Anglo Nubian $(\mathrm{n}=12)$, with initial body weight of $16.2 \pm 0.67 \mathrm{~kg}$, initial age of 3 months and confined during the growth phase. The treatments consisted of three diets: a standard diet formulated with a traditional protein source, the soybean meal (SM); and test diets, which consisted of a protein source alternative, differing detoxification processes, on the basis of calcium hydroxide $\left(\mathrm{Ca}(\mathrm{OH})_{2}\right)$ or sodium hydroxide $(\mathrm{NaOH})$. The animals were distributed in a completely randomized design, in factorial 3 x 2 (diet $\mathrm{SM}, \mathrm{Ca}(\mathrm{OH})_{2} \mathrm{DCC}$ and $\mathrm{NaOH} \mathrm{DCC} \times$ Saanen and Anglo Nubian) totaling six sessions with four replicates each. The experimental period lasted 270 days. The non-linear models used were the Gompertz and Logistic. There was no effect $(\mathrm{P}<0.05)$ of diets on the intake of nutrients, but there was no effect $(\mathrm{P}>0.05)$ of breeds and interaction between both factors. The intake of DM during the phase of growth was greater for the goats fed with SM. There was no effect $(\mathrm{P}>0.05)$ of diets nor of the breeds in the ADG. Feed conversion was influenced $(\mathrm{P}<0.05)$ by the diets, in which the goats fed diets with DCC presented better feed conversion. It has been observed that both models had good adjustments, with values numerically superior to $90 \%$, however, the logistic model showed higher $\mathrm{R}^{2}$ and, at the same time, asymptotic index (AI). Despite the ADG be equal, the breeds presented absolute growth rate (AGR) vary over time, where the Saanen goats reached the peak first
\end{abstract}

1 Prof., Universidade Estadual do Maranhão, UEMA, Itapecuru-Mirim, MA, Brasil. E-mail: ricardo_zoo@hotmail.com

2 Pesquisadores, Empresa Brasileira de Pesquisa Agropecuária, EMBRAPA Caprinos e Ovinos, Sobral, CE, Brasil. E-mail: robertopompeu@embrapa.br; marcos.claudio@embrapa.br; hevila.salles@embrapa.br

3 Discente do Curso de Doutorado do Programa de Doutorado Integrado em Zootecnia, Universidade Federal do Ceará, UFC/ UFRPE/UFPB, Departamento de Zootecnia, Fortaleza, CE, Brasil. E-mail: clesiosantzoo@gmail.com

4 Técnico, Empresa de Assistência Técnica Extensão Rural do Ceará, EMATERCE, Fortaleza, CE, Brasil. E-mail: renato.gomes. fontinele@hotmail.com

5 Discente do Curso de Doutorado do Programa de Pós-Graduação em Ciência Animal Tropical, Universidade Federal do Tocantins, PPGCAT, UFT, Araguaína, TO, Brasil. E-mail: luiza.zootecnia@gmail.com

Prof., Universidade Federal do Tocantins, UFT, Araguaína, TO, Brasil. E-mail: araguaia2007@gmail.com

* Author for correspondence 
(181 days), with AGR of $0.14 \mathrm{~kg} \mathrm{day}^{-1}$. However, even the goats Anglo Nubian reaching the highest peak late, the AGR was higher, around $0.16 \mathrm{~kg} \mathrm{day}^{-1}$ higher than the Saanen. Both castor cake has the potential to replace the SM on a diet of goat's kids during the growth phase. The mathematical model of Logistics estimates more accurately the growth of Saanen goats and Anglo Nubian, being that the rate of absolute growth is greatest in goats Anglo Nubian.

Key words: Anglo Nubian. Soybean meal. Non-linear model. Saanen.

\section{Resumo}

Objetivou-se avaliar a influência da substituição do farelo de soja (FS) pela torta de mamona destoxificada (TMD) por dois produtos alcalinos sobre o consumo, desempenho e na curva de crescimento de cabritas de aptidão leiteira. Foram utilizadas 24 cabras, Saanen $(n=12)$ e Anglo Nubiana ( $\mathrm{n}=12)$, com peso corporal inicial de 16,2 $\pm 0,67 \mathrm{~kg}$, idade inicial de 3 meses e confinadas durante a fase de crescimento. Os tratamentos consistiram de três dietas: dieta padrão formulada com uma fonte proteica tradicional, o farelo de soja (FS); e dietas testes, que consistiram de uma fonte proteica alternativa, diferindo os processos de destoxificação, à base de hidróxido de cálcio $\left(\mathrm{Ca}(\mathrm{OH})_{2}\right)$ ou hidróxido de sódio $(\mathrm{NaOH})$. Os animais foram distribuídos em delineamento inteiramente casualizado, em esquema fatorial $3 \times 2$ (dieta FS, TMD $\mathrm{Ca}(\mathrm{OH})_{2}$ e TMD NaOH x raça Saanen e Anglo Nubiana) perfazendo seis sessões com quatro repetições cada. O período experimental durou 270 dias. Os modelos não-lineares utilizados foram os de Gompertz e Logístico. Houve efeito $(\mathrm{P}<0,05)$ das dietas sobre o consumo dos nutrientes, porém não houve efeito $(\mathrm{P}>0,05)$ das raças e interação entre ambos os fatores. $\mathrm{O}$ consumo de MS durante a fase de crescimento foi maior para as cabras alimentadas com FS. Não houve efeito $(P>0,05)$ das dietas nem das raças no GMD. A conversão alimentar foi influenciada $(\mathrm{P}<0,05)$ pelas dietas, em que as cabras que consumiram as dietas com TMD apresentaram melhor conversão alimentar. Observou-se que ambos os modelos tiveram bons ajustes, com valores numericamente superiores a $90 \%$, contudo, o modelo Logístico apresentou maior R2 e, ao mesmo tempo, índice assintótico (IA). Apesar do GMD ser igual, as raças apresentaram taxa de crescimento absoluto (TCA) diferenciado ao longo do tempo, onde as cabras Saanen atingiram o pico primeiro (181 dias), com TCA de $0,14 \mathrm{~kg} \mathrm{dia}^{-1}$. Porém, mesmo as cabras Anglo Nubianas atingindo o pico mais tardiamente, a TCA foi maior, cerca de $0,16 \mathrm{~kg} \mathrm{dia}^{-1}$ superior às Saanen. Ambas as tortas tem potencial de substituir o FS em dieta de cabritas de aptidão leiteira durante a fase de crescimento. O modelo matemático Logístico estima de forma mais precisa o crescimento de cabras Saanen e Anglo Nubiana, sendo que a taxa de crescimento absoluto é maior em cabras Anglo Nubianas.

Palavras-chave: Anglo Nubiana. Farelo de soja. Modelo não-linear. Saanen.

\section{Introduction}

The physiological condition of the animal can change markedly ingestion of food. In the growth phase, for example, there is a significant variation, the amending markedly the growth of animals (Sarmento et al., 2016). Through nutrition it is possible to change the curve of growth of animals, and the effects of this amendment will vary depending on the degree and duration of manipulation (Guevara et al., 2018).

It should be emphasized that the animals in growth feature dry matter intake was closely linked to the body weight, at the rate of weight gain and the composition of the diet. In this way, due to the different diets offered, the growth of tissues is not isometric way (Owens, Dubeski, \& Hanson, 1993), considering that each tissue has growth profile is different, depending on the stage of development of the animal and the growth curves. In this way, the study of mathematical models it is important to characterize and foresees the possible effects of the diets and intrinsic characteristics of animals during the growth phase.

In the goat milk production, for example, so that the phase of lactation is efficiently productive, there 
is a need for goats well developed physiologically during the growth phase. Thus, the phase of rearing is of utmost importance, since the formation of healthy, well-nourished arrays and developed physiologically will reflect, subsequently, healthy pregnancies and lactations (Lôbo et al., 2017). It is worth mentioning that, in dairy goat farming systems, the principle, in the phase of growth, represent a major source of spending, especially with food, because they are in production. On this basis, the use of animal by-products from the biodiesel industry can make this phase more efficiently and reflect on the other, because the cause of growth determines the productive potential of the future dairy goat. In addition, you can reduce costs due to substitution of traditional products as the soybean meal.

Between the byproducts generated by the chain of biodiesel are the bran and the castor bean cake, since the cultivation of this crop grows each year, mainly by low demands on water and nutrients in the soil (Carrera et al., 2012; Cobianchi et al., 2012; Andrade et al., 2019). One of the main attractions for the use of the byproduct of castor oil in the feeding of ruminants is the high protein value. Being that the protein fraction has a high digestibility value, but lower than the soy bean (Borja et al., 2017), food standard in concentrate for ruminants. However, the byproducts of castor bean feature a nutritional limitation due to the presence of toxic proteins as the ricin and ricinus agglutinin (Dang \& Vam Damme, 2015). However, after the detoxification process of the castor bean cake can be a viable alternative to circumvent this situation and thus use it in animal feed (Araújo et al., 2018).

In this way, hypostatize that the use of the detoxified castor cake by alkaline solutions can replace soybean meal in diets without affecting the growth of dairy goats. In addition, this study aimed to evaluate the influence of the detoxified castor on intake, performance and growth curves of goats' kids saanen and Anglo Nubiana recreated in confinement.

\section{Materials and Methods}

All animal procedures were conducted in accordance with the regulations of the local Ethics Committee on the Use of Animals of the Brazilian Agricultural Research Corporation, National Center for Research with goats (case no. 005/2015). The chemical analyses were performed in the Laboratory of Animal Nutrition and Biochemistry of Embrapa Goats and Sheep, Sobral, Ceará, Brasil.

The study was conducted at the Technological Center of production of goat milk from Embrapa Goats and Sheep (344'57.42" south and $40^{\circ} 20^{\prime} 43.50^{\prime \prime}$ West) located in the city of SobralCE, Brazil. Were used twenty-four goats' kids (12 Saanen) and 12 (Anglo Nubian) with average body weight of $16.22 \pm 0.67 \mathrm{~kg}$. The treatments consisted of three diets, which consisted of: a standard diet formulated on the basis of Tifton 85 grass, corn, soy oil, limestone and soybean meal (SM); and two diets tests, which consist of a protein source alternative, differing detoxification processes: detoxified castor cake by calcium hydroxide $\left(\mathrm{Ca}(\mathrm{OH})_{2}\right.$ DCC) and detoxified castor by sodium hydroxide ( $\mathrm{NaOH}$ DCC ) in total replacement to SM.

It was used a completely randomized design with a factorial arrangement $3 \times 2$ (diet: $\mathrm{SM}, \mathrm{Ca}(\mathrm{OH})_{2}$ DCC and $\mathrm{NaOH}$ DCC x breed: Saanen and Anglo Nubian) totaling six sessions with four replicates each. The goats were subjected to a regime of confinement in individual stalls, suspended and with floor ripped of $5.06 \mathrm{~m}^{2}$, being $2.87 \mathrm{~m}^{2}$ composed by solarium, provided of drinkers, feeders and salt shakers. In the pre-experimental conditions, goats were identified, treated against ecto- and endoparasites, and administered rabies vaccine.

The experimental diets were formulated based on the recommendations of the National Research Council [NRC] (2007) for average daily weight gain of $100 \mathrm{~g}$. All diets were isonitrogenous with roughage:concentrate ratio average of 40:60 (Table 1 and 2). 
The diets were given daily at 8:00 and 16:00 hours, in order to allow $10 \%$ of the supply in leftovers. During the experimental period were collected samples of concentrates provided and leftovers, then were conditioned in plastic bags and stored in a freezer at $-18{ }^{\circ} \mathrm{C}$. The samples were thawed and submitted to a pre-drying in forced ventilation oven at $55{ }^{\circ} \mathrm{C}$ for 72 hours. Then, crushed in mills of knife (Wiley mill, Arthur H. Thomas, Philadelphia, PA, USA).

Table 1

Chemical composition of the ingredients used for the preparation of the experimental diets

\begin{tabular}{|c|c|c|c|c|c|}
\hline \multirow{2}{*}{ Item $\left(\mathrm{g} \mathrm{kg} \mathrm{DM}^{-1}\right)$} & \multicolumn{5}{|c|}{ Ingredients } \\
\hline & Tifton 85 hay & Ground corn & Soybean meal & $\mathrm{Ca}(\mathrm{OH})_{2}, \mathrm{DCC}$ & $\mathrm{NaOH}$ DCC \\
\hline Dry matter ( $\mathrm{g} \mathrm{kg}^{-1}$ fresh matter) & 872.50 & 889.20 & 870.20 & 904.20 & 904.80 \\
\hline Organic matter & 911.30 & 965.90 & 956.90 & 867.70 & 855.60 \\
\hline Mineral matter ${ }^{1}$ & 88.70 & 34.10 & 43.10 & 132.30 & 144.40 \\
\hline Crude protein & 104.10 & 79.50 & 443.30 & 315.40 & 309.00 \\
\hline Ether extract & 14.50 & 36.80 & 28.80 & 52.10 & 47.50 \\
\hline Total carbohydrates & 792.80 & 845.70 & 484.70 & 500.10 & 492.60 \\
\hline Non-fiber carbohydrates & 277.80 & 722.40 & 320.80 & 103.90 & 132.40 \\
\hline Neutral detergent fiber & 722.70 & 184.60 & 217.80 & 483.40 & 443.50 \\
\hline NDFap & 514.90 & 123.20 & 163.80 & 396.10 & 360.10 \\
\hline Acid detergent fiber & 472.20 & 69.00 & 117.90 & 379.20 & 388.70 \\
\hline Lignin & 60.60 & 8.80 & 12.20 & 50.70 & 46.10 \\
\hline Total digestible nutrients & 546.80 & 848.00 & 822.50 & 620.50 & 627.90 \\
\hline Digestible energy $\left(\mathrm{MJ} \mathrm{kg}^{-1} \mathrm{DM}\right)$ & 100.70 & 155.90 & 151.30 & 114.10 & 112.00 \\
\hline Metabolizable energy $\left(\mathrm{MJ} \mathrm{kg}^{-1} \mathrm{DM}\right)$ & 82.80 & 139.20 & 134.20 & 96.60 & 94.10 \\
\hline Net energy $\left(\mathrm{MJ} \mathrm{kg}^{-1} \mathrm{DM}\right)$ & 50.60 & 81.50 & 79.00 & 58.50 & 56.80 \\
\hline
\end{tabular}

${ }^{1} \mathrm{Ca}(\mathrm{OH})_{2}$ DCC: $0.90 \mathrm{~g} \mathrm{Na} \mathrm{kg}^{-1} \mathrm{DM}$ and $2.25 \mathrm{~g} \mathrm{Ca} \mathrm{kg}^{-1} \mathrm{DM}$; NaOH DCC: $29.20 \mathrm{~g} \mathrm{Na} \mathrm{kg}^{-1} \mathrm{DM}$ and $0.63 \mathrm{~g} \mathrm{Ca} \mathrm{kg}^{-1} \mathrm{DM}$. 
Table 2

Ingredient proportions and chemical compositions of the experimental diets

\begin{tabular}{|c|c|c|c|}
\hline \multirow{3}{*}{ Ingredient $\left(\mathrm{g} \mathrm{kg} \mathrm{DM}^{-1}\right)$} & \multicolumn{3}{|c|}{ Diets } \\
\hline & Soybean meal & $\mathrm{Ca}(\mathrm{OH}), \mathrm{DCC}$ & $\mathrm{NaOH} \mathrm{DCC}$ \\
\hline & \multicolumn{3}{|c|}{ Proportion of ingredients in the diets $\left(\mathrm{g} \mathrm{kg} \mathrm{DM}^{-1}\right)$} \\
\hline Tifton 85 hay & 427.30 & 394.90 & 363.20 \\
\hline Ground corn & 460.80 & 481.90 & 504.60 \\
\hline Soybean meal & 57.80 & -------- & -------- \\
\hline Detoxified castor cake & -------- & 83.30 & 82.90 \\
\hline Soy oil & 45.00 & 39.90 & 39.20 \\
\hline Limestone & 9.10 & 0.01 & 10.10 \\
\hline Mineral mixture $^{1}$ & Ad libitum & Ad libitum & Ad libitum \\
\hline \multicolumn{4}{|l|}{ Chemical composition $\left(\mathrm{g} \mathrm{kg} \mathrm{DM}^{-1}\right)$} \\
\hline Dry matter $\left(\mathrm{g} \mathrm{kg}^{-1}\right.$ fresh matter $)$ & 887.70 & 896.10 & 891.80 \\
\hline Organic matter & 942.30 & 897.80 & 938.10 \\
\hline Mineral matter & 57.70 & 102.20 & 61.90 \\
\hline Crude protein & 112.00 & 112.90 & 112.30 \\
\hline Neutral detergent insoluble protein & 13.10 & 13.20 & 12.40 \\
\hline Acid detergent insoluble nitrogen & 3.70 & 3.90 & 4.10 \\
\hline Ether extract & 62.00 & 63.40 & 65.40 \\
\hline Total carbohydrates & 761.40 & 721.20 & 751.80 \\
\hline Non-fiber carbohydrates & 471.80 & 468.60 & 476.80 \\
\hline Neutral detergent fiber (NDF) & 408.80 & 409.00 & 392.30 \\
\hline NDF corrected for ash and protein & 338.00 & 293.60 & 318.00 \\
\hline Acid detergent fiber & 349.50 & 332.00 & 305.40 \\
\hline Lignin & 30.80 & 32.60 & 30.30 \\
\hline Total digestible nutrients & 664.90 & 658.50 & 663.60 \\
\hline Digestible energy $\left(\mathrm{MJ} \mathrm{kg}^{-1} \mathrm{DM}\right)$ & 12.30 & 12.10 & 12.20 \\
\hline Metabolizable energy $\left(\mathrm{MJ} \mathrm{kg}^{-1} \mathrm{DM}\right)$ & 10.50 & 10.40 & 10.50 \\
\hline Net energy $\left(\mathrm{MJ} \mathrm{kg}^{-1} \mathrm{DM}\right)$ & 6.30 & 6.20 & 6.30 \\
\hline
\end{tabular}

${ }^{1}$ Guaranteed level (per kg, inactive elements): calcium - 218 g; phosphorus - 71 g; sulfur - 20 g; manganese - 1.300 mg; potassium - $28.20 \mathrm{mg}$; cobalt - $30 \mathrm{mg}$; selenium - $15.30 \mathrm{mg}$; zinc $-1700 \mathrm{mg}$; copper $=710 \mathrm{mg}$.

Weighing's were performed with intervals of 15 days, always in the morning, being that the 270 days it was determined the final body weight (BWf), to assess the performance of goats. To calculate the average daily gain (ADG), took into consideration: $\mathrm{ADG}=((\mathrm{BWf}-\mathrm{BWinitial}) /$ days in confinement $)$. For the calculation of the feed conversion (FC) took into account the intake of dry matter (DMI) and average daily gain $(\mathrm{ADG})\left(\mathrm{FC}=\mathrm{ADG} \mathrm{DMI}^{-1}\right)$.

In food samples (leftovers and supplied) were determined the levels of dry matter (method no 934.01), organic matter (method no 942.05), crude protein (method no 954.01), ether extract (method no 920.39) in accordance with the Association of Analytical Chemists [AOAC] (2003). For the analysis of neutral detergent fiber (NDF), samples were treated with alpha-amylase thermostable, without the use of sodium sulphite and corrected for residual ash.

The neutral detergent fiber (NDF) and acid detergent fiber (ADF) were analyzed from the methodology described by Detmann et al. (2012). The content of non-fibrous carbohydrates (NFC) was calculated using the NDFap. The TDN values were calculated and then converted into net energy (NE) and digestible energy (DE), using the 
equations suggested by NRC (2001). The intake of TDN was calculated by the formula: $T D N I=(C P I-$ $\mathrm{CPf})+2.25$ (EEI-EEf) $+(\mathrm{CHOI}-\mathrm{CHOf})$, in that CPI, $\mathrm{EEI}$ and $\mathrm{CHOI}$ mean intakes of $\mathrm{CP}, \mathrm{EE}$ and $\mathrm{CHO}$, respectively, and $\mathrm{CPF}$, EEf and $\mathrm{CHOf}$, levels of $\mathrm{CP}$, $\mathrm{EE}$ and $\mathrm{CHO}$ in the feces.

For the analysis of the growth curve, the data were adjusted to two non-linear models: Logistical, $\mathrm{Y}=\mathrm{A}\left(1+\mathrm{Be}^{-\mathrm{Kt}}\right)-1+\varepsilon$ and Gompertz, $\mathrm{Y}=\mathrm{Ae} \mathrm{Be} e^{(-\mathrm{Kt}}$ )$+\varepsilon$. The $Y$ value is understood as body weight in function of age $\mathrm{t}$; A, asymptotic weight; $\mathrm{B}$, constant of integration; value of $\mathrm{K}$ is understood as the rate of maturity, which is interpreted as a change of weight in relation to the weight and maturity. Or, as an indicator of the speed with which the animal reaches its adult weight.

For the adjustment of non-linear models, we used the iterative procedure in view of which depends on the own estimated parameters, unlike the linear models that can be estimated directly (Sarmento et al., 2016). The criteria used to define the quality of adjustment of the model were: Residual Mean Square (RMS), obtained from the division of the sum of squares of the residue of the model by number of observations, the shorter the better fit of the model. According to the methodology proposed by Sarmento et al. (2016), was calculated as the mean absolute deviation (MAD), asymptotic index (AI) and AIC (Akaike's criterion's Information Criterion). After choosing the model that best adjusted to the data for each breed were performed contrast of the curves of each diet to check the effect on the growth curve of Saanen and Anglo Nubian, it was estimated a curve for each diet and then were compared according to the following hypothesis: Ho: $\mathrm{A}_{\text {diet1 }}=\mathrm{A}_{\text {diet2 }}=\mathrm{A}_{\text {diet3 }}, \mathrm{B}_{\text {diet1 }}=\mathrm{B}_{\text {diet2 }}=\mathrm{B}_{\text {diet3 }}=, \mathrm{k}_{\text {diet1 }}$ $=\mathrm{k}_{\text {diet2 }}=\mathrm{k}_{\text {diet3 }}=$ Ha: At least one of the equalities is difference.

Diet $1=$ Animals receiving the diet of soybean meal; Diet $2=$ Animals receiving diet the basis of detoxified castor cake by calcium hydroxide $\left(\mathrm{Ca}(\mathrm{OH})_{2} \mathrm{DCC}\right)$; Diet $3=$ Animals receiving diet the basis of detoxified castor cake by sodium hydroxide ( $\mathrm{NaOH} \mathrm{DCC})$.

The curves were adjusted by means of the procedure NLINMIXED statistical program SAS $^{\circledR}$ (Edition University, SAS Institute Inc., Cary, NC, USA, Cody 2015). The effect of the curves between the diets were contrasted by means of the command ESTIMATE of NLINMIXED procedure, in which it was observed that the difference between the parameters of the curves were inside (there was no difference between the parameters of the curves) or not (there was a difference between the parameters of the curves) of the interval of confidence interval at the level of $95 \%$.

Intake data and weight gain were submitted to tests of normality (Shapiro-Wilks) and homoscedasticity (Levene's test), and completed the presuppositions, were submitted to analysis of variance test by $F$. analyzes were performed from the following model:

$$
Y i j k=\mu+\alpha i+\beta j+(\square \beta) i j+e i j k
$$

Where Yilk is the dependent variable corresponding to the experimental observation; $\mu$ is the general mean; $\alpha i$ is the fixed effect of diets; $\beta \mathrm{j}$ is the fixed effect of breed; $(\alpha \beta) \mathrm{ij}$ is the effect of interaction between diets and breeds; and eijk is the random error, assuming a normal distribution. The interaction between diet and breed was split only when significant at $5 \%$ probability. To evaluate the effects of diet and breed, we proceeded to the comparison of means by Tukey test at 5\% probability. Statistical analyzes were performed using the MIXED procedure of $\mathrm{SAS}^{\circledR}$ computer program (Edition University, SAS Institute Inc., Cary, NC, USA, Cody 2015).

\section{Results and Discussion}

Our results showed an effect of the diets on the consumption of DM ( $\mathrm{P}=0.02)$, as well as an effect of $\mathrm{DM}$ in relation to body weight $(\mathrm{P}=0.01), \mathrm{CP}$ $(\mathrm{P}=0.03)$, EE $(\mathrm{P}=0.02)$, NDF $(\mathrm{P}=0.04)$, and TDN 
$(\mathrm{P}=0.03)$. No effects of the breed or interactions between factors were observed. Goats fed the SM diet showed a higher intake of DM, both in $\mathrm{g} \mathrm{day}^{-1}$ and in \% of body weight (BW) (Table 3). Similarly, the intake of $\mathrm{CP}$ was higher under $\mathrm{SM}$ and $\mathrm{Ca}(\mathrm{OH})_{2}$ DCC diets, and this same trend was also observed for EE intake, although there was no difference in the intake between goats that received $\mathrm{Ca}(\mathrm{OH})_{2}$ DCC and those that consumed $\mathrm{NaOH}$ DCC. Finally, goats fed DCC showed higher intake of TDN; 741.67 and $717.14 \mathrm{~g} \mathrm{day}^{-1}$ for $\mathrm{Ca}(\mathrm{OH})_{2}$ DCC and $\mathrm{NaOH}$ DCC, respectively.

In the diet containing SM, the value of DM intake was higher than that recommended by the National Research Council (NRC, 2007). The NRC recommends that dairy goat kids with an average daily gain of $100 \mathrm{~g}$ like the ones we studied should consume an average of $910 \mathrm{~g} \mathrm{DM} \mathrm{day}^{-1}$. However, the goats that consumed the DCC-based diets had better use of the feeds when compared to those that consumed the SM-based one. This was probably due to the lack of effect on ADG (Table 4) besides the higher feed conversion, the lower intake of other nutrients, and the lower intake of DM, which was probably due to the presence of $\mathrm{Na}$ and $\mathrm{Ca}$ in the diets (Araújo et al., 2018). This response may be associated with three factors, the first being a reduction in the ingestion of these nutrients by the animals, resulting in a longer stay of this material in the gastrointestinal tract, what ultimately favors digestibility. The second factor would be the high digestibility of DCC by a possible hydrolysis of the fibers during the detoxification process. This occurs because the alkaline products act on the fibrous fraction of the plant cell by promoting a rupture of the hydrogen bridges, leading to an expansion of the cellulose molecules that become more susceptible to the action of cellulolytic enzymes. They also cause the solubilization of hemicellulose because of the rupture of the ester-type bonds of hemicellulose with lignin (Pires, Carvalho, \& Ribeiro, 2010; Missio, 2016). The third factor would be the volume: concentrate ratio of diets with DCC (40:60 and 36: 64 for $\mathrm{Ca}(\mathrm{OH})_{2}$ and $\mathrm{NaOH}$, respectively), which gave them a possible higher digestibility, contributing to a probable shorter rumination time (Araújo et al., 2018, 2019), thus reducing intake (Giger-Reverdin, Rigalma, Desnoyers, Sauvant, \& Duvaux-Ponter, 2014). 
Table 3

Dry matter intake (DMI) in grams per day and in\% of body weight (BW), crude protein (CPI), ether extract (EEI), neutral detergent fiber (NDFI) and total digestible nutrients (TDNI) for goats' kids fed diets with detoxified castor cake to replace soybean meal

\begin{tabular}{|c|c|c|c|c|c|c|c|c|}
\hline \multirow{3}{*}{ Breed } & \multicolumn{3}{|c|}{ Diets } & \multirow{3}{*}{ Mean } & \multirow{3}{*}{ SEM $^{1}$} & \multicolumn{3}{|c|}{ P-value } \\
\hline & Soybean meal & $\mathrm{Ca}(\mathrm{OH})_{2} \mathrm{DCC}$ & $\mathrm{NaOH} \mathrm{DCC}$ & & & & & \\
\hline & \multicolumn{3}{|c|}{ DMI $\left(\mathrm{g} \mathrm{day}^{-1}\right)$} & & & Diet & Breed & $\mathrm{D} \times \mathrm{B}$ \\
\hline Saanen & 1039.33 & 904.195 & 867.355 & 936.96 & \multirow{2}{*}{32.442} & \multirow{2}{*}{0.020} & \multirow{2}{*}{0.430} & \multirow{2}{*}{0.240} \\
\hline Anglo Nubian & 1004.65 & 914.61 & 816.69 & 911.983 & & & & \\
\hline \multirow[t]{2}{*}{ Mean } & $1021.99 \mathrm{a}$ & $909.403 b$ & $842.023 b$ & & \multirow{4}{*}{0.431} & & & \\
\hline & & DMI (\% B & & & & \multirow{3}{*}{0.01} & \multirow{3}{*}{0.221} & \\
\hline Saanen & 3.00 & 2.55 & 2.49 & 2.68 & & & & \multirow{2}{*}{0.152} \\
\hline Anglo Nubian & 2.80 & 2.68 & 2.30 & 2.59 & & & & \\
\hline \multirow[t]{2}{*}{ Mean } & $2.90 \mathrm{a}$ & $2.61 \mathrm{~b}$ & $2.39 \mathrm{~b}$ & & \multirow{4}{*}{4.231} & \multirow{4}{*}{0.03} & \multirow{4}{*}{0.076} & \multirow{4}{*}{0.134} \\
\hline & & CPB $\left(\right.$ g day $\left.^{-1}\right)$ & & & & & & \\
\hline Saanen & 119.675 & 106.36 & 101.575 & 109.203 & & & & \\
\hline Anglo Nubian & 115.705 & 107.125 & 94.945 & 105.925 & & & & \\
\hline \multirow[t]{2}{*}{ Mean } & $117.69 \mathrm{a}$ & $106.743 b$ & $98.26 b$ & & \multirow{4}{*}{2.543} & & & \\
\hline & & EEI $\left(\right.$ g day $\left.^{-1}\right)$ & & & & & & \\
\hline Saanen & 67.02 & 60.88 & 60.21 & 62.70 & & \multirow{2}{*}{0.02} & \multirow{2}{*}{0.248} & \multirow{2}{*}{0.206} \\
\hline Anglo Nubian & 64.73 & 60.65 & 56.83 & 60.74 & & & & \\
\hline \multirow[t]{2}{*}{ Mean } & $65.88 \mathrm{a}$ & $60.76 \mathrm{~b}$ & $58.52 \mathrm{~b}$ & & \multirow{4}{*}{1.985} & \multirow{4}{*}{0.04} & \multirow{4}{*}{0.187} & \multirow{4}{*}{0.137} \\
\hline & & $\operatorname{NDFI}\left(\mathrm{g} \mathrm{day}^{-1}\right)$ & & & & & & \\
\hline Saanen & 396.99 & 338.84 & 318.67 & 351.50 & & & & \\
\hline Anglo Nubian & 392.85 & 353.88 & 312.02 & 352.92 & & & & \\
\hline \multirow[t]{2}{*}{ Mean } & $394.92 \mathrm{a}$ & $346.36 \mathrm{~b}$ & $315.34 b$ & & & & & \\
\hline & & TDNI $\left(\mathrm{g} \mathrm{day}^{-1}\right)$ & & & & & & \\
\hline Saanen & 687.81 & 738.21 & 739.36 & 721.79 & & & & \\
\hline Anglo Nubian & 664.85 & 745.14 & 694.93 & 701.64 & 27.872 & 0.03 & 0.168 & 0.203 \\
\hline Mean & $676.33 b$ & $741.67 \mathrm{a}$ & $717.14 \mathrm{a}$ & & & & & \\
\hline
\end{tabular}

${ }^{1}$ Mean standard error. Averages followed by common lowercase letters in the lines and by uppercase letters in the columns do not differ from one another according to the Tukey test at $5 \%$ significance. 
Table 4

Average daily gain (ADG) and feed conversion (FC) in goats' kids fed diets with detoxified castor cake to replace soybean meal

\begin{tabular}{|c|c|c|c|c|c|c|c|c|}
\hline \multirow{3}{*}{ Breed } & \multicolumn{3}{|c|}{ Diets } & \multirow{3}{*}{ Mean } & \multirow{3}{*}{ SEM $^{1}$} & \multicolumn{3}{|c|}{ P-value } \\
\hline & Soybean meal & $\mathrm{Ca}(\mathrm{OH})_{2} \mathrm{DCC}$ & $\mathrm{NaOH}$ DCC & & & Diet & Breed & $D \times B$ \\
\hline & \multicolumn{3}{|c|}{$\mathrm{ADG}\left(\mathrm{g} \mathrm{day}^{-1}\right)$} & & & Diet & Breed & $D \times B$ \\
\hline Saanen & 109.08 & 115.13 & 98.43 & 107.54 & \multirow{3}{*}{6.913} & \multirow{2}{*}{0.565} & \multirow{2}{*}{0.610} & \multirow{2}{*}{0.601} \\
\hline Anglo Nubian & 110.20 & 99.43 & 100.56 & 103.40 & & & & \\
\hline \multirow[t]{2}{*}{ Mean } & $109.64 \mathrm{a}$ & $107.28 \mathrm{a}$ & $99.49 \mathrm{a}$ & & & & & \\
\hline & & $\mathrm{FC}\left(\mathrm{kg} \mathrm{kg}^{-1}\right)$ & & & \multirow{4}{*}{0.632} & \multirow{4}{*}{0.014} & \multirow{4}{*}{0.874} & \multirow{4}{*}{0.419} \\
\hline Saanen & 9.34 & 8.58 & 8.65 & 8.86 & & & & \\
\hline Anglo Nubian & 9.37 & 8.54 & 8.52 & 8.81 & & & & \\
\hline Mean & $9.36 \mathrm{~b}$ & $8.56 \mathrm{a}$ & $8.59 a$ & & & & & \\
\hline
\end{tabular}

${ }^{1}$ Mean standard error. Averages followed by common lowercase letters in the lines and by uppercase letters in the columns do not differ from one another according to the Tukey test at 5\% significance.

Regarding the intake of EE, it was observed that the values for all diets were higher than the maximum recommended for ruminants, which is up to $6 \%$ DM. Such increases were due to the addition of soy oil in the diets to meet energy requirements required by rumen bacteria (Kozloski, 2011). The higher consumption of TDN with the inclusion of castor bean cakes can be justified by a higher digestibility of the nutritional fractions of diets containing this ingredient. According to the NRC (2007), the intake of TDN for this category of growing goats is 420 to $500 \mathrm{~g} \mathrm{day}^{-1} \mathrm{TDN}$ to gain approximately $100 \mathrm{~g}$ day $^{-1}$ body weight. The intake of TDN has a direct relation with the energy consumed by ruminants, so we can infer that the substitution of soybean meal by DCC in diets did not reduced the intake.

During this study, no effect of the diets on the ADG $(\mathrm{P}=0.565)$ nor effect of the breed were observed (Table 4); nevertheless, feed conversion was influenced $(\mathrm{P}=0.01)$ by the different diets, being the goats that consumed DCC-containing diets the ones that had better feed conversion. Thus, the absence of effect of the inclusion of castor cake on the performance of the goats during the rearing phase justifies the potential use of DCC independently of the alkaline product used in detoxification. However, it is worth to consider the cost of the protein in relation to the available conventional protein sources. Another important factor to be considered is that the treatment handling of castor bean cake, as the treatment with sodium hydroxide. presents some inconveniences, such as greater care in handling, excess sodium in diet, feces, and urine, and environmental contamination problems (Nascimento, Carvalho, Freitas, \& Souza, 2016).

Despite the decrease in NDF intake by the goats that received the diets with DCC, the observed amount is above the minimum daily requirement, which is $25 \% \mathrm{DM}$. It was expected that more NDF would be consumed by the DCC-fed goats, as an intrinsic feature of this food is the high NDF content; as the diets were isofibrous, the difference in consumption could actually be a consequence of variation in DM intake. These findings are in line with those obtained by Gionbelli et al. (2014) and Palmieri et al. (2016), who evaluated the effect of inclusion of detoxified castor cake in lamb diets and also observed a decrease in intake of NDF.

It is interesting to note that our performance data contradict the data in the literature, where 
Anglo Nubian goats were traditionally considered to be of double aptitude and consequently greater weight gains were expected when compared to the Saanen. However, no difference in performance between both breeds was observed. The greatest feed conversion for the goats that received the diets with DCC is probably related to the possible higher digestibility of the diet, as previously mentioned. Nicory et al. (2015) evaluated the substitution of soybean meal by castor oil meal in lamb diets and did not observe any effect on average daily, total, and feed conversion gains.
We observed that, among the models compared, Gompertz's showed higher value for parameter A in both breeds, being 62.89 for Saanen and 78.62 for Anglo Nubian (Table 5). Parameter A represents the asymptotic weight, which can be interpreted as weight at maturity. In fact, the model accurately expresses the weight of goats for these breeds considering that they were purebred animals_-, with the Anglo Nubians being heavier, a characteristic related to their double aptitude. On the other hand, parameter B represents the integration constant, and it is only used to adjust the initial value of live weight and has no biological value.

\section{Table 5}

Parameters estimated by the Logistic and Gompertz Models for performance of goats' kids fed diets with detoxified castor cake to replace soybean meal

\begin{tabular}{llccccccc}
\hline \multirow{2}{*}{ Breed } & \multirow{2}{*}{ Models } & \multicolumn{3}{c}{ Parameters } & \multirow{2}{*}{ R2 } & \multirow{2}{*}{ MAD $^{4}$} & AI $^{5}$ & \multirow{2}{*}{ AIC $^{6}$} \\
\cline { 3 - 5 } \multirow{2}{*}{ Saanen } & Logistic & 47.86 & 6.22 & 0.0085 & 0.992 & 12.29 & 0.722 & 699.30 \\
& Gompertz & 62.89 & 2.34 & 0.0038 & 0.982 & 15.44 & 0.895 & 702.90 \\
\multirow{3}{*}{ Anglo Nubian } & Logistic & 54.48 & 6.85 & 0.0093 & 0.998 & 14.60 & 0.708 & 802.80 \\
& Gompertz & 78.62 & 2.51 & 0.0045 & 0.978 & 18.64 & 0.900 & 870.80 \\
\hline
\end{tabular}

${ }^{1}$ Value interpreted as average weight at maturity. ${ }^{2}$ Integration constants. ${ }^{3}$ Value that expresses the maturity rate. ${ }^{4}$ Mean absolute deviation. ${ }^{5}$ Asymptotic index. ${ }^{6}$ Akaike Information Criterion.

From a practical point of view, $k$ is the most important of the three parameters in the growth curve studies, since it represents the speed with which the animal reaches the asymptotic weight, i.e. the maturity rate. According to Malhado, Carneiro, Affonso, Sousa and Sarmento (2009), animals with higher $k$ values show a precocious maturity in relation to those with lower $k$ values and similar initial weight. We observed that, regardless of the model studied, Anglo Nubian goats had higher speed, which may be related to their double aptitude. Based on the coefficients of determination $\left(\mathrm{R}^{2}\right)$, both models had good adjustments, with numerical values higher than 90\%. However, the logistic model presented a higher $\mathrm{R}^{2}$, a lower mean absolute deviation (MDA), and a lower asymptotic index
(AI). This criterion combining $\mathrm{R}^{2}$ and DMA results of paramount importance in decision making.

To estimate the best fit model, we considered the Akaike information criterion (AIC), which admits the existence of a "real" model that describes unknown data and tries to choose among a group of evaluated models. This minimizes the divergence, what allows us to state that the model with the lowest value for AIC is considered the best fit model. It should be noted that for both breeds, the logistic model presented the best fit, with values of 699.30 and 802.80 for Saanen and Anglo Nubian goats, respectively. In view of this, it can be concluded that the logistic model can estimate the growth of Saanen and Anglo Nubian goats more accurately, as shown in Figure 1. Despite the similarity observed 
in the curves, growth models allow for forecasts and interpretations within this age range, which is important for the development of healthy, early, and good milk/producer goats. Thus, it is possible to use maturity rate estimates to identify earlier animals within the studied age range.
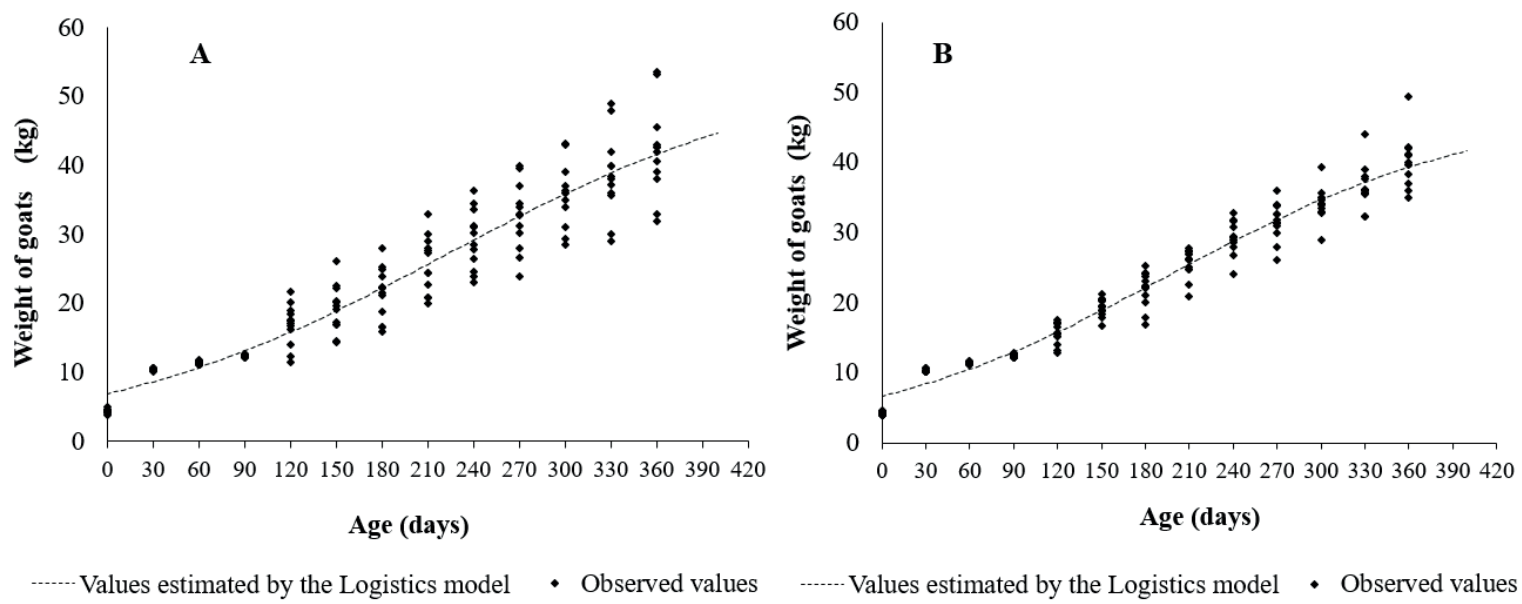

Figure 1. Growth curves according the Logistic Model selected for the performance of Saanen (A) and Anglo Nubian (B) breeds.

After choosing the best model to explain the growth of the goats in both breeds, we estimated the parameters under the influence of the different diets (Table 6). In relation to adult goats weight (A), it is interesting to note a certain variation, both between breeds and diets; Saanen goats fed SM-based diets showed a higher A $(56.01 \mathrm{~kg})$, followed by Anglo Nubian goats fed $\mathrm{Ca}(\mathrm{OH})_{2}$ DCC diets $(51.40 \mathrm{~kg})$. On the other hand, Saanen goats fed DCC had lower adult weight (46.21 and $43.97 \mathrm{~kg}$ for those fed $\mathrm{Ca}(\mathrm{OH})_{2} \mathrm{DCC}$ and $\mathrm{NaOH} \mathrm{DCC}$ diets, respectively), regardless of the detoxification process. Previous studies showed differences regarding the optimal adult size of an animal, which depends on both the species and the breed after selection practice, as well as the management system adopted and the climatic conditions (Magalhães, Lobo, \& Facó, 2013; Sarmento et al., 2016).

Table 6

Parameters estimated by the Logistic Model selected for the performance of goats' kids fed diets with detoxified castor cake to replace soybean meal

\begin{tabular}{lcccc}
\hline \multirow{2}{*}{ Breed } & \multirow{2}{*}{ Diets } & \multicolumn{3}{c}{ Parameters } \\
\cline { 3 - 5 } & & $\mathrm{A}$ & $\mathrm{B}$ & $\mathrm{k}$ \\
\hline \multirow{3}{*}{ Saanen } & Soybean meal & 56.01 & 6.50 & 0.008 \\
& $\mathrm{Ca}(\mathrm{OH})_{2}$ DCC & 46.21 & 6.03 & 0.009 \\
& $\mathrm{NaOH}$ DCC & 43.97 & 5.89 & 0.010 \\
\hline \multirow{3}{*}{ Anglo Nubian } & $\mathrm{S}$ & 49.71 & 7.10 & 0.010 \\
& $\mathrm{Ca}(\mathrm{OH})_{2}$ DCC & 51.40 & 8.96 & 0.007 \\
& $\mathrm{NaOH}$ DCC & 49.29 & 6.11 & 0.009 \\
\hline
\end{tabular}


We verified that there was no difference between the diets on the growth curve of each breed from the contrast established between the curve parameters. Therefore, the use of a single growth curve adjusted with the logistic model was stablished as standard (Table 5; Figure 1). In relation to the integration constant (B), we observed higher values for Anglo Nubian goats, with an average of 7.39, while Saanen goats had an average value of 6.14 for B. Regarding the effects of the diets on the integration constant, Anglo Nubian goats consuming the $\mathrm{Ca}(\mathrm{OH})_{2}$ DCC diet presented higher B values (8.96) than Saanen goats fed NaOH DCC diet (5.89). On the other hand, Saanen goats fed the $\mathrm{NaOH}$ DCC diet and Anglo Nubian goats fed the SM Standard diet shared both the highest maturity rate $(0.010)$, which indicates a higher precocity in the animals fed these diets.

The absolute growth rate (AGR) estimated by the logistic model is shown in Figure 2. Despite the fact that the ADG is the same (Table 4), the breeds had differentiated AGR over time, with Saanen goats peaking first ( 181 days, $A G R=0.14 \mathrm{~kg} \mathrm{day}^{-1}$ ). Anglo Nubian goats reached their peak later, albeit their AGR was higher at about $0.16 \mathrm{~kg} \mathrm{day}^{-1}$. According to Owens et al. (1993), the growth of young goats from birth under appropriate environmental conditions is described by a sigmoid curve with two distinct phases, which are characterized by quite different trends. In Phase I i.e. from the beginning of the experiment until $240+10$ days the growth is accelerated and consequently the animals have higher rates of weight gain activated by the release of growth hormones thyroxine and somatotropin. Moreover, the synthesis of muscle tissue is greater in relation to fat, and consequently the intake of SM is higher. Phase II is characterized by a reduction in the intensity of body growth, with less weight gain and greater deposition of adipose tissue, thus presenting lower intake of DM.

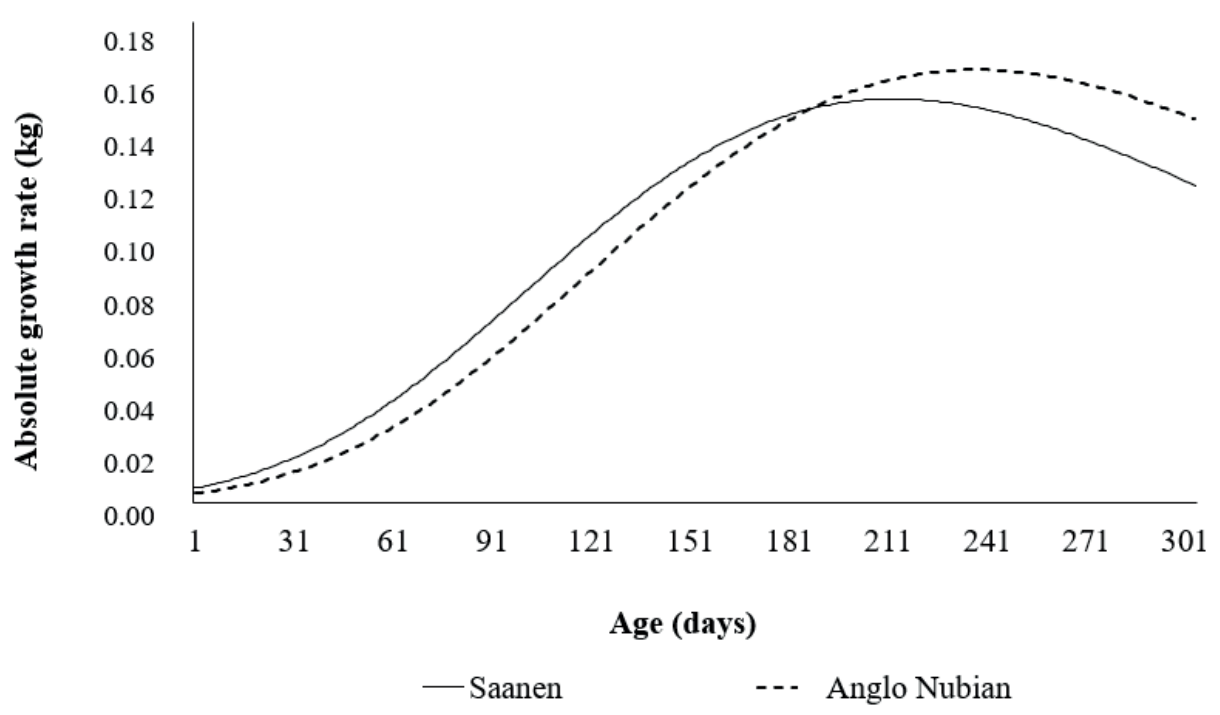

Figure 2. Absolute growth rate estimated by the Logistic Model selected for the performance of Saanen and Anglo Nubiana breeds. 


\section{Conclusions}

Our results showed that castor bean cakes detoxified with calcium hydroxide $\left(\mathrm{Ca}(\mathrm{OH})_{2}\right)$ or sodium hydroxide $(\mathrm{NaOH})$ have the potential to replace soybean meal on a diet of dairy goats kids during the growth phase, as they do not adversely affect the growth in both Anglo Nubian and Saanen breeds. Goats which consume detoxified castor cake diets have lower dry matter and nutrient intake but have better feed conversion. We conclude that the most accurate mathematical model to estimate the growth of both goat breeds is the logistic.

\section{References}

Andrade, I. R. A., Cândido, M. J. D., Pompeu, R. C. F. F., Feitosa, T. S., Bomfim, M. A. D., Salles, H. O., \& Egito, A. S. (2019). Inactivation of lectins from castor cake by alternative chemical compounds. Toxicon, 160(915), 47-54. doi: 10.1016/j.toxicon.2019.02.003

Araújo, R. A., Neiva, J. N. M., Pompeu, R. C. F. F., Cândido, M. J. D., Rogério, M. C. P., Lucas, R. C.,... Egito, A. S. (2018). Feeding behavior and physiological parameters of rearing goats fed diets containing detoxified castor cake. Semina: Ciências Agrárias, 39(5), 2247-2260. doi: 10.5433/16790359. 2018 v39n5p2247

Araújo, R. A., Neiva, J. N. M., Rogério, M. C. P., Pimentel, P. G., Furtado, R. N., Mariz, L. D. S.,... Pompeu, R. C. F. F. (2019). Ingestive behavior and physiological parameters of lactating goats fed diets containing detoxified castor cake. Biological Rhythm Research, 50(1) 1-11. doi: 10.1080/ 09291016. 2019.1594120

Association of Analytical Chemists (2003). Official methods of analysis (17th, 2nd, rev.) Gaithersburg, M. D.: AOAC.

Borja, M. S., Oliveira, R. L., Silva, T. M., Bezerra, L. R., Nascimento, N. G., Jr., \& Borja, A. D. P. (2017). Effectiveness of calcium oxide and autoclaving for the detoxification of castor seed meal in finishing diets for lambs. Animal Feed Science and Technology, 231(9), 76-78. doi: 10.1016/j.anifeedsci.2017.07.001

Carrera, R. A. B., Veloso, C. M., Knupp, L. S., Souza, A. H. S., Jr., Detmann, E., \& Lana, R. P. (2012). Protein co-products and by-products of the biodiesel industry for ruminants feeding. Revista Brasileira de Zootecnia, 41(5), 1202-1211. doi: 10.1590/S151635982012000500018
Cobianchi, J. V., Oliveira, A. S., Campos, J. M. S., Guimarães, A. V., Valadares, S. C., F ${ }^{\circ}$., Cobianchi, F. P., \& Oliveira, T. E. S. (2012). Productive performance and efficiency of utilization of the diet components in dairy cows fed castor meal treated with calcium oxide. Revista Brasileira de Zootecnia, 41(10), 2238-2248. doi: 10.1590/S151635982012001000015

Dang, L., \& Van Damme, E. J. M. (2015). Toxic proteins in plants. Phytochemistry, 117(1), 51-64. doi: 10. 1016/j.phytochem.2015.05.020

Detmann, E., Souza, M. A., Valadares, S. C., Fº, Queiroz, A. C., Berchielli, T. T., Saliba, E. O. S.,... Azevedo, J. A. G. (2012). Métodos para análise de alimentos - INCT - Ciência animal. Visconde do Rio Branco: Suprema.

Giger-Reverdin, S., Rigalma, K., Desnoyers, M., Sauvant, D., \& Duvaux-Ponter, C. (2014). Effect of concentrate level on feeding behavior and rumen and blood parameters in dairy goats: Relationships between behavioral and physiological parameters and effect of between-animal variability. Journal of Dairy Science. 97(7), 4367-4378. doi: 10.3168/ jds.2013-7383

Gionbelli, T. R. S., Veloso, C. M., Gionbelli, M. P., Novais, M. A. S., Silva, A. L., Espechit, C. J. B.,... Duarte, M. S. (2014). Utilization of castor bean meal treated with calcium hydroxide fed wet or dry by lambs. Livestok Science, 168(1), 76-783. doi: 10.1016/j.livsci.2014.08.012

Guevara, C. E., Rodrigues, M. T., Vieira, R. A. M., Silva, M. C., Lima, M. C., \& Hernandez Herrera, D. (2018). Modelos não lineares para descrever o consumo, deposição de nutrientes no corpo e crescimento de cabritos Saanen x Alpina. Archivos de Zootecnia, 67(257), 41-53. doi: 10.21071/az.v67i257.3490

Kozloski, G. V. (2011). Bioquímica dos ruminantes (3a ed.). Santa Maria: UFSM.

Lôbo, A. M. B. O., Lôbo, R. N. B., Facó, O., Souza, V., Alves, A. A. C., Costa, A. C., \& Albuquerque, M. A. M. (2017). Characterization of milk production and composition of four exotic goat breeds in Brazil. Small Ruminant Research, 153(1), 9-16. doi: 10.1016/j.smallrumres.2017.05.005

Magalhães, A. F. B., Lobo, R. N. B., \& Facó, O. (2013). Genetic parameters estimates for growth traits in Somalis Brasileira hair sheep breed. Ciência Rural, 43(5), 884-889. doi: 10.1590/S0103-847820130050 00043 
Malhado, C. H. M., Carneiro, P. L. S., Affonso, P. R. M., Sousa, A. A. O., Jr., \& Sarmento, J. L. R. (2009) Growth curves in Dorper sheep crossed with the local Brazilian breeds, Morada Nova, Rabo Largo, and Santa Inês. Small Ruminant Research, 84(1), 1621. doi: 10.1016/j.smallrumres.2009.04.006

Missio, R. L. (2016). Treatment of sugarcane bagasse for ruminant feed. Archivos de Zootecnia, 65(250), $267-$ 278. doi: $10.21071 /$ az.v65i250

Nascimento, T. V. C., Carvalho, G. G. P., Freitas, J. E., Jr., \& Souza, W. F. (2016). Volumosos tratados com aditivos químicos: valor nutritivo e desempenho de ruminantes. Archivos de Zootecnia, 65(252), 593604. doi: 10.21071/az.v65i252.1932

National Research Council (2001). Nutrient requirements of dairy cattle. Washington DC: National Research Council. The National Academies Press.

National Research Council (2007). Nutrient requirements of small ruminants: sheep, goats, cervids, and new world camelids. Washington DC: The National Academies Press.

Nicory, I. M. C., Carvalho, G. G. P., Ribeiro, O. L., Santos, S. A., Silva, F. F., Silva, R. R.,... Freitas, J. E., Jr. (2015). Productive and metabolic parameters in lambs fed diets with castor seed meal. Livestok Science, 18(1), 171-178. doi: 10.1016/j. livsci.2015.09.015
Owens, F. N., Dubeski, P., \& Hanson, C. F. (1993). Factors that alter the growth and development of ruminants. Journal Animal Science, 71(11), 31383150. doi: 10.2527/1993.71113138x

Palmieri, A. D., Carvalho, G. G. P., Tosto, M. S. L., Leite, V. M., Santos, S. A., Borja, M. S.,... Rufino, L. M. A. (2016). Nutritional and productive performance of goats kids fed diets with detoxified castor meal. Animal Feed Science and Technology, 216(2), 81-92. doi: 10.1016/j.anifeedsci.2016.03.015

Pires, A. J. V., Carvalho, G. G. P., \& Ribeiro, L. S. O. (2010). Chemical treatment of roughage. Revista Brasileira de Zootecnia, 39(Supl.), 192-203. doi: 10.1590/S1516-35982010001300022

Sarmento, J. L. R., Torres, R. A., Sousa, W. H., Lôbo, R. N. B., Albuquerque, L. G., Lopes, P. S.,... Bignardi, A. B. (2016). Random regression models for the estimation of genetic and environmental covariance functions for growth traits in Santa Ines sheep. Genetics and Molecular Research, 15(2), 1-13. doi: 10.4238/gmr.15025749

Statistical Analysis System Institute (2016). SAS ${ }^{\circledR}$ Studio. User's guide (version 3. 5). Cary, NC: SAS Institute Inc. 